\title{
UTILIZATION OF BANK RESERVES IN THE UNITED STATES AND FOREIGN COUNTRIES
}

\author{
By Hon. George E. Roberts, \\ Director of the United States Mint, Washington, D. C.
}

The cash reserve feature of the banking systems of the United States, state as well as national, is peculiar to this country. Nowhere else is a fixed reserve required against deposits. The central banking institutions of Europe are commonly required to keep a contain minimum metallic reserve against their note issties, although there is a notable exception even to this in the case of the Bank of France, but in all foreign countries the question of a proper cash reserve against deposits is left to the discretion of the banker.

The practices and regulations of foreign banking systems are all characterized by this comparative indifference to deposits and emphasis upon the importance of the note issues. On the continent of Europe this may be accounted for in part by the fact that deposit banking is yet undeveloped to any such degree as it is in England or the United States, and the private cheque has not yet taken the place of circulating notes, as it has done to a great extent in these two countries. The common medium of payments in Germany and France is the bank note, while in England and the United States it is the private cheque. The custom of keeping a bank account is much more common in these two countries than anywhere else in the world, and this of course accounts in part for our being more interested in the security for deposits while elsewhere the interest is in security for the circulating notes.

But England, although like ourselves in the use of the bank account and cheque, is like the continental countries in its indifference to cash reserves for deposits. There, too, all emphasis is laid upon the convertibility of the bank note. So far is this true that when the constitution of the Bank of England was reformed in 1844 and provision was made that its issues above a certain amount must be fully covered by gold, the authors of the act seem to have thought the bank absolutely fortified against attack, although no provision had been made to meet a run by depositors. This weak-

$$
(523)
$$


ness developed within three years, in the panic of 1847 , when the demands on the banking department were so heavy that its cash would have been exhausted had not the government authorities taken the responsibility of advising the bank management to disregard the restrictions of the act and issue notes to meet the emergency. Twice since then, the last time in I866, the same policy has been resorted to, with the result that although the law has never been changed, public opinion has settled down to the conclusion that the restrictions upon note issues will always be ignored when cash is actually needed. To this day, however, no legal reserve against deposits is required of either the Bank of England or the jointstock banks of that country, and neither in England nor any continental country do any of the banks except the Central Bank show in their published statements the amount of their cash holdings. In all of these countries the banks report their credits at the Central Bank as cash, and commonly they report cash, credit at the Central Bank, and money at call or short notice in one item. Their reliance is not upon cash reserves, nor even upon balances at the Central Bank, but chiefly upon their holdings of commercial paper of a class which the Central Bank will always take off their hands.

The national banking system of the United States originally required a fixed cash reserve against both deposits and outstanding notes, but in 1874 the note reserve in the individual banks was dispensed with,- and the five per cent redemption fund for notes was established in the treasury at Washington. This fund, however. although set apart for the current redemption of notes, is still included and counted in the required reserve for deposits.

No change has been made in the reserve requirements for deposits since the establishment of the system. Banks in what are known as the central reserve cities, of which there are now three, New York, Chicago and St. Louis, must keep cash reserves in their own offices equal to twenty-five per cent of their deposits. Banks in what are denominated the reserve cities, of which there are now forty-six, must keep reserves of twenty-five per cent, but one-half may consist of balances in the national banks of the central reserve cities. The other banks of the system must keep reserves of fifteen per cent, but three-fifths of these may be kept with the national banks of the reserve and central reserve cities. There is no penalty for the violation of these provisions, but the law forbids the making of loans 
while a bank is below the requirement and authorizes the Comptroller of the Currency in his discretion to have a receiver appointed.

The law as to reserves is not, of course, enforced with the same uncompromising rigor as those provisions which relate to the fundamental principles of banking. Every comptroller, while acknowledging it to be his duty to see that the reserve requirements are respected and ordinarily observed, has recognized that their literal enforcement at all times is utterly impracticable. No bank can control the amount of its cash holdings, for it must pay cash on demand and can only replenish its reserves by reducing its loans, and conditions may be such that to stop making loans and attempt to force collections will not only make collections impossible but create a state of panic that will greatly stimulate cash withdrawals. It is now a recognized principle of banking all over the world that in a crisis the banks should lend freely to all responsible borrowers, and no comptroller of the currency has ever insisted that a national bank should refuse to make any loans while its legal reserves were impaired. They have contented themselves with exerting pressure for the restoration of the reserves as soon as reasonably possible. In fact the law has been construed as a grant of authority to the comptroller enabling him to supervise the reserves and keep them as nearly as practicable at the prescribed proportions.

The provision of the statute which allows the banks in the smaller towns and cities to keep a portion of their reserves in the reserve cities, and the reserve city banks to keep a portion of their reserves in the central reserve cities, has been often criticised, and several secretaries of the treasury have recommended its repeal, but it simply recognizes the fact that banks are obliged to keep important cash balances in the central cities and that they pay off their depositors by means of these balances as well as over their own counters. The country banks would have to maintain balances in these cities whether the law allowed them to count in the reserves or not, in order to furnish exchange to their customers. And while these balances are sometimes larger than would be required by the needs of their exchange business, the surplus represents money not needed at home, and there is as good an argument in favor of gathering the idle capital of various localities into a central pool, where it will be available for other sections of the country which may have a seasonal use for it, as there is for gathering the idle 
hoards of individuals into banks. This feature of our law is an approximation to the banking practices of other countries, and of course accomplishes a very important modification of the reserve requirements.

It is safe to say as a rule that the country banks and banks of the reserve cities carry more cash in vault than the law requires and would carry no less if there was no legal requirement. They carry considerably greater cash reserves than similarly situated banks in other countries, and feel obliged to because they do not have the same certainty of help from outside in an emergency. On the other hand, the banks of our central reserve cities, which must furnish the final support for the whole system in an emergency, run with much smaller reserves than the central banking institutions of Europe are accustomed to carry, and it is in this scattering of reserves as compared with their concentration in foreign systems that the weakness of our system appears.

The law contemplates that the banks of the central reserve cities shall hold the final reserves of the national banking system and in this respect have a relationship to the other banks similar to that of the central banks of Europe to the other banks there. But with us there is no such concentration of responsibility or special equipment for supporting the situation as there is over there. The national banks of our central reserve cities have no privileges or advantages or special powers. The number is in no way limited; there are many of them, and they are under the stress of sharp competition not only with each other, but with the state banks and trust companies in their own cities and with the banks of rival cities. It has been demonstrated that no agreement to cease paying interest can be maintained under the pressure of these conditions, and this fact alone puts them in a radically different position from the state banks of Europe. None of the latter pays interest and all agree that the practice is inconsistent with the conservative policy which should be followed by a bank holding the final reserves for a country. It is impossible to pay interest on deposits and keep the proportionate reserves that a bank carrying this responsibility should keep.

The Bank of France, at the date of its latest statement, ${ }^{1}$ held in cash $\$ 860,492,329$ against a total of all liabilities, including notes 
and public and private deposits, of $\$ 1,166,368,45 \mathrm{I}$, or a reserve of seventy-eight per cent. This illustrates its deliberate and consistent policy, and makes plain why the other banks of France may implicitly rely upon it for assistance and need carry only small supplies of cash themselves.

When the National Monetary Commission was in Europe in I909, seeking information from the leading financial authorities about the banking systems and practices of the different countries, it held interviews with M. Pallain, Governor of the Bank of France, and with the heads of the principal joint-stock banking companies of Paris, in which the relations of the Bank of France to these other institutions were clearly developed. The following is an extract from the interview with M. Pallain:

Q. The published balance sheets of the banks do not state separately the amount in the Bank of France and the amount in their own vaults.

A. In the credit establishments which you will visit you will be able to establish the fact that the liquid cash is, in comparison with their turnover, relatively very small. In France we consider that the strength of a bank consists more in the composition of its portfolio, $i . e$., in the value of its commercial bills, rather than in the importance of its cash reserve.

Q. In America the question of the proper relation between cash in hand and liabilities is considered very important.

A. It appears to us that for French private banks the proportion of cash to liabilities is less significant on account of the facilities offered by the organization of the Bank of France for the rapid conversion-in a crisis-of a good portfolio into ready money.

Q. We are trying to inform ourselves as to the usages and customs of foreign banks. It is for this reason that we seek to ascertain the percentage of cash which the banks hold to their deposit liabilities.

A. I think I have already replied on this point. The part which the Bank of France plays toward the private establishments permits the latter, as has many a time been proved, to reduce to a minimum their cash reserves, and to devote, without exceptional risk, a larger part perhaps than elsewhere to productive commercial operations.

In an interview with Baron Brincard, of the Credit Lyonnais, an institution with approximately $\$ 300,000,000$ of deposits, the following questions and answers occurred:

Q. Is it customary for yout to carry quite a large amount of cash in your vault?

A. Every day the amotnt of cash which is to be kept here in our 
vaults is fixed according to the payments to be made during the day. Sometimes our holdings are greatly in excess of our forecast for disbursements. This happens when we do not find ready use for amounts available.

$Q$. You would not carry a larger amount of cash in vault than required by your daily needs in order that it may serve as a part of your reserve?

A. There is no legal requirement for a reserve in cash; the bank is quite free to keep the amount of cash that it judges necessary. It is the practical business experience of many years which indicates how much cash is needed for the day.

$Q$. So the cash in hand is merely carried for the necessities of business?

A. Yes; this is the point on which the French situation is quite different from the American, because in France bankers are free to have in their vaults any amount of cash they like. In France we have the Bank of France which regulates the currency of the whole country, and any bank, if it has need for additional cash, may present for rediscount at the Bank of France the bills and other commercial paper which it has in its vaults. The amount we carry in the Bank of France may vary greatly according to circumstances. It is not to our advantage to have too large a sum at the bank, because the Bank of France does not allow any interest.

Q. What per cent of your deposits do you intend to carry in cash either in your own vaults or in other banks?

A. Eight to ten per cent on the average. The excess of deposits is invested almost entirely in commercial paper available for discount with the Bank of France at any moment and in "reports" (loans or securities from one stock exchange settlement to another).

$Q$. You have nearly ten per cent in this statement?

A. That is perhaps more than we need. It is a matter of practical experience. There is no legal proportion.

It will be seen that the percentage of cash kept in the bank's own vaults is not given, but its cash and cash balance at the Bank of France were together eight or ten per cent of its deposits. The commission went further into the availability of the short time commercial paper as a banking reserve, as follows:

Q. If the Credit Lyonnais were to take bills to the Bank of France for rediscount, would the Bank of France scrutinize those bills beyond the number of signatures and the time they have to run?

A. It would scrutinize the number of signatures and the time. In every branch of the Bank of France there is a committee called the discount committee, which is charged to make inquiries as to the quality of the industrial and business men of the region, and on their advice those persons are or are not admitted to discount. When once a person is admitted to discount the question of his credit is not raised every time that he presents a bill for discount; but if he should offer too many bills the bank would doubtless call 
his attention to the fact. In practice no one has ever complained that the Bank of France would not discount a normal bill presented by a proper person.

Q. As a matter of fact, bills offered by the Credit Lyonnais would not be investigated very carefully?

A. No.

Q. You regard that item of bills discounted as your practical reserve because of your ability to rediscount the bills at the Bank of France?

A. Yes; bills discounted and cash are, for an establishment such as ours, the most essential part of our liquid assets.

In the interview with M. Ullman, Director of the Comptoir d'Escompte, another great French institution, the following colloquy occurred :

Q. Is the Bank of France your principal reliance in case you need money? Do you think it necessary to carry any additional reserve?

A. Under our French system we consider the commercial paper we keep in the portfolio a cash reserve, as we can rediscount it at the Bank of France. We know the Bank of France will discount these bills and thus enable us to convert the bills instantly into cash; this is the basis of the French banking system.

The Imperial Bank of Germany, or Reichsbank, performs practically the same functions in Germany that the Bank of France does in France. It does not run ordinarily with as strong a cash reserve, for the position of the Bank of France is unique and due in part to the peculiar position of France as a creditor nation with a constant influx of gold. But at the date of the latest statement available at this writing, the Reichsbank held cash reserves equal to seventy-five per cent of its outstanding notes, and above fifty per cent of all liabilities, including the government deposits. In an interview with the Monetary Commission last year, the vice-president of the bank stated that the lowest point ever touched by its reserve was 40.3 per cent, at the close of 1905 .

There are no restrictions upon the power of this institution to issue notes except the requirement that a reserve of thirty-three and one-third per cent of cash shall be held against them and the levy of a five per cent tax upon the excess above a certain amount. And even this reserve requirement, like that of the Bank of England and that of the national banks of the United States, is not to be taken too literally, for when the Monetary Commission asked Herr 
Dr. von Glasenapp, vice-president, what the bank would do if the reserve fell to thirty-two per cent, he replied:

We should have to go on discounting bills. We should simply have to do it. We could not stop it If we did it would bring on the greatest panic that we ever experienced.

In other words, the Reichsbank recognizes its responsibility as the keeper of the final banking reserves, and will not cease in a crisis to supply credit and currency to meet the needs of the other banks of the country. This attitude gives absolute confidence to the public.

In the interview held by the Monetary Commission with Herr Paul Mankiewitz, director of the Deutsche Bank, he said:

The great strength of our financial system in Germany is the Reichsbank. Under that system the question of our own cash reserve is of secondary importance, as we can at all times convert our holdings of commercial paper into cash at the Reichsbank. I may mention that of the prime commercial bills we are carrying from $\$ 1,500,000$ to $\$ 2,000,000$ fall due each day; for these we get cash or credit at the Reichsbank at maturity. It is our usual practice to keep in vaults and banks a considerable amount of cash, often nore than ten per cent, and sometimes less, perhaps eight per cent.

This reserve of eight or ten per cent, including cash in bank and credit at the central bank, corresponds to similar figures in France.

In England the practice of counting balances with the central bank as a part of the cash resources prevails as on the Continent, and the other institutions as a rule carry only so much cash in their own offices as they estimate will be needed to meet current demands. Of late, however, a considerable body of opinion has developed to the effect that the burden of providing the gold reserve for the London market is too great to be thrown upon the Bank of England alone. London is the chief international clearing center and the transactions in gold there are very much more important than in any other market of the world. A financial disturbance in any country causes a demand upon London for gold, and it sometimes comes with alarming insistence, as in the case of the American demand of I907. Although there is no complaint that the Bank of England has not ably and effectively performed the functions 
which belong to a central banking institution, the importance of London as the banking and clearing metropolis of the world, has developed so enormously, that the bank has become a relatively smaller institution than formerly, having been passed in volume of business and assets by several of the joint-stock banks. Under these conditions, it has been urged that the other banks should bear some part of the burden of protecting the London market from the unusual demands to which, by reason of its international relations, it is exposed, and some steps to this end have been taken. The average reserve of the banking institutions which center in London, in cash and balances at the Bank of England, have been estimated at fourteen to twenty per cent. As the Bank of England's reserve is from forty to fifty per cent, the average of cash in bank to the total of individual deposits in Great Britain is probably eight or ten per cent.

In the United States, taking only individual deposits in order to avoid duplication, the total for all banks is reported by the Comptroller of the Currency on April 28, 1909, in round numbers as follows :

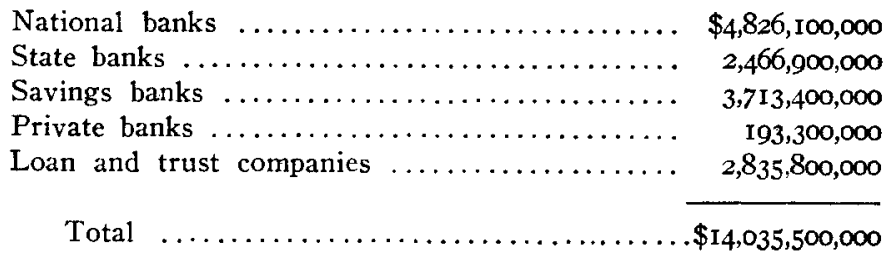

The cash holdings were as follows:

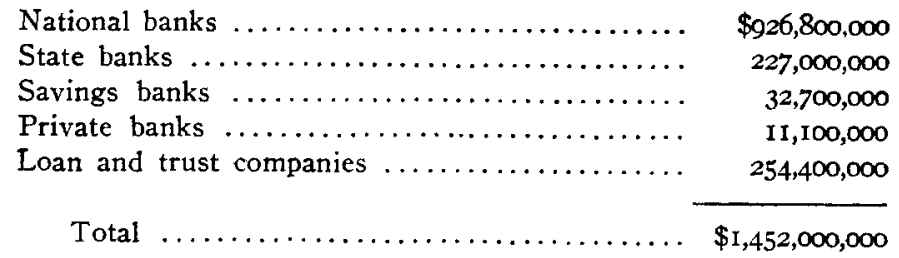

or about ten per cent. The actual percentage of cash to liabilities does not appear to be very different from what it is in the three countries reviewed above, but there is no denying that a more effective utilization is obtained in every one of the three than in the 
United States. We have more money in the individual banks, but no final banking reserve of sufficient strength to inspire confidence. The ability of the final supporting power, be it a single bank or a group of banks, to give aid to the other banks of the system in a crisis, lies of course in the resources kept ordinarily in reserve. The central reserve banks of our national system are required to keep a reserve of twenty-five per cent and forbidden to make any loans when they are below this figure. Granting that this inhibition is not strictly enforced, it remains true that they are under pressure to maintain their reserves at this point. How much surplus reserve do they usually have above it? The following are the percentages of each city at the date of every official statement from August 22, 1907, which was the last statement preceding the panic:

\begin{tabular}{|c|c|c|}
\hline August $22,1907 \ldots \ldots \ldots \ldots \ldots{ }_{26.81}^{\text {New York. }}$ & $\begin{array}{c}\text { Chicago. } \\
25.34\end{array}$ & $\begin{array}{l}\text { St. Louis. } \\
23.59\end{array}$ \\
\hline December 3, I907 & $24.2 \mathrm{I}$ & 20.38 \\
\hline February 14, 1908 ........ 29.00 & 27.14 & 28.98 \\
\hline May $14,1908 \ldots \ldots \ldots \ldots \ldots, 30.52$ & 26.82 & 28.86 \\
\hline July $15,1908 \ldots \ldots \ldots \ldots \ldots .28 .37$ & 26.59 & 25.52 \\
\hline September $23,1908 \ldots \ldots \ldots \ldots \quad 28.65$ & 25.12 & $25.4 \mathrm{r}$ \\
\hline November $27,1908 \ldots \ldots \ldots \ldots, 26.02$ & 25.94 & $25.7 \mathrm{I}$ \\
\hline February $5,1909 \ldots \ldots \ldots \ldots .25 .58$ & 25.99 & 26.52 \\
\hline April $28, \quad 1909 \ldots \ldots \ldots \ldots, 25.68$ & 26.16 & 25.44 \\
\hline June 23, I909 $\ldots \ldots \ldots \ldots \ldots .27 .27$ & 25.73 & 25.21 \\
\hline September I, Igog ......... 25.83 & 24.30 & 2472 \\
\hline November 15, I909 $\ldots \ldots \ldots \ldots 25.52$ & 24.29 & 24.80 \\
\hline January 31, I910 ........... 26.64 & 24.12 & 24.05 \\
\hline March 29, I910 ........... 25.76 & 23.35 & 22.36 \\
\hline
\end{tabular}

These figures show practically no surplus reserves. It is true that all of these banks have a considerable proportion of their loans at call or upon short maturities and any one of them would be able to liquidate rapidly under normal conditions, when it was the only one under pressure. But when a general situation develops and there is a common movement to liquidate, there are no other resources in this country to draw upon and nothing to be done but to sell securities or products or negotiate loans abroad, any of which is a slow and costly process of getting relief in a crisis.

The scattered reserves in local banks are of no avail in a panic. Whether they average five per cent or twenty per cent makes little difference, for the banks that are strong feel none too strong and 
will hoard every dollar. Gathered into a central fund they would aggregate a sum great enough to inspire confidence and could be brought to bear at the point of danger to protect every situation.

The most serious result of this fundamental weakness at the center is the lack of confidence which pervades the whole system and the readiness on the part of thousands of individual banks to take alarm and do, for the purpose of self-protection, the very thing that precipitates a crisis. The general suspension of cash payments in 1907 was unnecessary. Outside of New York City depositors were not alarmed but taken completely by surprise by the emergency measures adopted. The natural impulse of the scattered banks to strengthen themselves forced a suspension of payments in the reserve cities and literally broke down the system.

The essential thing required to prevent or allay panics is knowledge that there is a central reserve of credit strong enough to provide every solvent bank and business house with ample support. Periods of industrial reaction and of speculative collapse are bound to come occasionally in every country. Private credit is strained at such a time, solvency is put to the test, and the unsound concerns are weeded out. It is of supreme importance at such a time that banks and business houses which are really solvent shall not be broken down and destroyed through inability to obtain the ordinary consideration to which their assets entitle them. There is literally no limit to which disorganization may go unless there is some power strong enough to stay the panic by interposing its undoubted credit to protect the firms and concerns that it finds to be worthy. This fund of credit the great central institutions of Europe afford, but the machinery of our national banking system does not supply.

The Bank of France and the Reichsbank have the power of actually increasing the supply of money in the country. The Bank of England does not have this power by statute, but as we have seen has three times exercised it, and these instances have satisfied the public that it will be exercised whenever it is necessary. The ability to draw checks on the central institution is all that the banks of any country in Europe ordinarily require to meet the demands upon them.

We have already in the United States a gold reserve great enough to be made the basis of an institution more powerful than any one of those which have been named. The treasury held in the 
division of redemption on the Ist day of July, I9Io, a reserve of $\$ 862,936,869$ in gold coin against outstanding demand certificates of exactly the same amount. The volume of these certificates is always completely covered, and as a government issue properly so. If, however, an institution designed to support the credit system of this country was created, and its notes were made available for the same purposes for which gold certificates are used, they might be substituted for the latter in circulation. In doing so, the treasury certificates would pass into the hands of this new organization and be presented at the treasury for redemption. Thus the reserve would be transferred to the new institution and, starting with a reserve of one hundred per cent, it could take a place in and behind the banking system of this country similar to that held by the great central institutions of Europe in their systems.

The only problem about it is to provide an organization that will be acceptable to the country as giving assurance that the institution will be kept out of politics and not fall under the control of private or special interests. It is generally recognized that the best way to accomplish this is by keeping the management in the hands of the bankers of the country. The capital of the bank, say $\$ 100,000,000$, might be raised by selling the stock under a guaranty by the government of a low rate dividend, say four per cent. But, if the stock is sold broadcast the control should be taken away from it, and might be vested in a board of directors elected by the leading clearing houses of the country. Suppose the first twenty-five or thirty clearing houses leading in clearings for the preceding year were incorporated and each allowed to elect one member of a board: Based on the clearings of the first six months of Igro the membership would then be distributed over the country as follows: Boston, New York, Baltimore, Richmond, Buffalo, Cleveland, Chicago, Milwaukee, St. Paul, Kansas City, Louisville, New Orleans, Denver, Los Angeles, Portland, Providence, Philadelphia, Washington, Pittsburg, Detroit, Cincinnati, Indianapolis, Minneapolis, Omaha, St. Louis, Atlanta, Houston, Salt Lake, San Francisco, Seattle.

Another plan suggested is to distribute the stock with the local banks of the country on the basis of their capital. The national banks could be either required to subscribe or offered inducements to do so, and if they paid in ten per cent of their capital that would provide about $\$ 100,000,000$. The directors should be elected by dis- 
tricts, so that every section of the country would be represented on the board by a member of its own choosing. Under either of these plans the board of directors would have, through the personal knowledge of its members, all of whon would be bankers of high standing, the most thorough acquaintance with business conditions over the country that could possibly be obtained. Each member would be there as the representative of the bankers of his locality and the bankers of every locality are so closely identified with all its business interests that the latter would be safe in their hands.

The members of the board would naturally be divided in their political affiliations and there is no more reason to believe that political considerations would influence their action than there is to expect the clearing houses to suddenly become political agencies.

The active and responsible officers of the bank should be chosen by this board, but to satisfy public opinion and because of the intimate relations which this institution would bear to the treasury, there may well be another board, supervisory in its functions, representing the government. It might consist of three important officials of the Treasury Department and perhaps two outside members of banking experience, appointed by the President. It would doubtless be advisable to divide the profits between shareholders and the treasury on some such plan as exists in Germany, AustriaHungary and elsewhere.

It would not be necessary or desirable to have this central institution do a general banking business with the public, or to even hold the reserves of the local banks. It should be established with the slightest possible disturbance of existing banking conditions. For it to undertake to hold the reserves of country banks would involve an enormous shifting of funds from present channels, and, what is more serious, cause a concentration of loanable funds which is distinctly undesirable. The resources of the proposed Central Bank are to be kept largely in reserve. If the present reserves of country banks are taken from the city reserve agents, who now hold them and loan them, and transferred to a central institution which will keep them mainly in reserve, there will be a very heavy and unnecessary loss of working capital to the country. The relations of the country banks to their present reserve correspondents should not be disturbed, but back of the reserve cities and central reserve cities there should be the new central institution 
holding the concentrated gold reserve as the basis for a great fund of credit which may be drawn upon as needed.

The country banks should not only be encouraged to keep their reserve or surplus funds with their city correspondents as heretofore, but should be encouraged to get their accommodations there as well. There are forty-six reserve cities and many other important towns where the banks actually carry reserves for smaller banks in nearby towns and make loans to them. These relationships have developed naturally, are based upon intimate acquaintance, and should not be disturbed. Let them all be part of a system at the head of which shall be the Central Bank of Issue. By the use of all these agencies the distribution of credit can be more effectually secured than by attempting to have all of the small banks of this great country do business directly with the Central Bank.

Nor is it necessary or desirable to retire the bond-secured currency, at least at the present time. It is a practically fixed amount and serves the purpose of a circulating medium. To retire it would involve refunding the outstanding two per cents and, what is more serious, it would involve providing $\$ 700,000,000$ of currency to fill the void in our currency stock. Future issues of government bonds should be on an investment basis, but the outstanding national bank issues may well be left undisturbed until the bonds upon which they are based are retired.

One of the most important services which a Central Bank could render would be that of handling the treasury funds. The present practice of distributing them, arbitrarily, among the national banks is a continual vexation to the Secretary of the Treasury, subjecting him to constant importunity and criticism. And there is no way of relieving him except by creating a strong responsible agency which shall have such relations to the banking and commercial community that it can handle the large and rapidly growing receipts and disbursements without disturbance.

The common objection to a Central Bank of Issue, i. $\boldsymbol{c}$., that it would be related to Wall Street and become involved in speculative transactions, is made without knowledge of the functions and practices of such institutions elsewhere. Nowhere are stocks or bonds permitted to be used as the basis of note issues. Everywhere short time commercial paper, representing actual commodities moving to market or in process of production, is required. Wall Street has no 
means of creating such paper. A ninety-day bill of exchange, drawn by a Minneapolis milling company and accepted by a solvent merchant, based on a car load of flour, cannot be duplicated in Wall Street. We show our ignorance of world methods when we profess our inability to discriminate between legitimate banking and stock company promotion, or our inability to safeguard the former from the latter. And it is not too much to say that such a state of financial deadlock as existed in the United States in 1907 is a reflection upon the intelligence of the American people and of their moral capacity to do business by the most advanced methods. 